\title{
Exchange Rate Determination in Pakistan: A Simultaneous Equation Model
}

\author{
REHANA SIDDIQUI, USMAN AFRIDI, and ZAFAR MAHMOOD
}

\begin{abstract}
In recent years the gap between real exchange rate (RER) and nominal exchange rate (NER) has widened in Pakistan. A proper understanding of the determinants of real exchange rate can be extremely useful for the management of current account deficit. The results of this study show that the Simultaneous Equation Model gives better results than the Single Equation Model. The estimated coefficients reveal that changes in both monetary and real sector variables affect the equilibrium path of RER. The distinction between traded and non-traded goods can also help in proper real exchange rate management.
\end{abstract}

\section{INTRODUCTION}

The exchange rate provides a key link between a country and the rest of the world, both in goods and assets markets. Poor exchange rate policy risks misrepresenting trade opportunities resulting in misallocation of resources. A competitive and stable real exchange rate (RER) should, therefore, be the optimal policy target. ${ }^{1}$

Pakistan has been persistently facing a current account deficit. For the past many years, speculation of currency devaluation has resulted in massive capital flight from the country. Such a disturbing situation calls for an in-depth analysis of the real exchange rate determination which should guide the policy-makers to adjust exchange rate towards its equilibrium path. The present study focuses on the role of monetary and real variables in determining the equilibrium path of real exchange rate.

Interestingly, in Pakistan, changes in NER seem to result in relatively stable RER. It can be noted from Figure 1 that the average growth rate of RER is slower than the average growth rate of NER. ${ }^{2}$ This comparison indicates that real devaluation in currency is much smaller than the nominal devaluation. In fact, in recent years, the graph gap between the RER and the NER has widened sharply [see Figure 1]. An

Rehana Siddiqui and Usman Afridi are both Senior Research Economist and Zafar Mahmood is Chief of Research at the Pakistan Institute of Development Economics, Islamabad.

${ }^{1}$ Pakistan adopted a fixed exchange rate policy upto 1982 and a managed floating exchange rate policy afterwards.

${ }^{2}$ The estimated equations of RER and NER are:

$$
\begin{aligned}
\ln (R E R)= & 2.0013+0.026 T \\
& (41.85) \quad(11.29) \\
\ln (N E R)= & 1.229+0.058 T \\
& (22.55) \quad(22.10)
\end{aligned}
$$




\section{Figure 1}

obvious reason for the rising gap is that the domestic inflation is higher than the foreign inflation. The sharply rising gap between the two exchange rates, i.e., NER and RER, calls for policy actions to maintain an equilibrium path of RER.

Empirical studies for Pakistan, and for other developing and developed countries show that both real and monetary variables play an important role in the determination of real exchange rate. ${ }^{3}$ Afridi (1995), for instance, shows that excess domestic credit creation, ratio of net capital inflow to gross domestic product, and "openness" of the economy are all important variables to determine the equilibrium path of the RER. However, he finds a statistically insignificant impact of the terms of trade and the technological change on the RER. Another study for Pakistan, by Chishti and Hasan (1993), shows that domestic credit creation and the level of deficit-financing are important variables which influence the equilibrium path of the real exchange rate.

Most empirical studies, though provide basis for exchange rate management, ignore the important issue of inter-dependence between RER, and some explanatory variables like openness and net foreign capital inflow. ${ }^{4}$ In this study, we develop a small simultaneous equations model for Pakistan and estimate it by utilising the data for the period 1960 to 1994. The paper is organised as follows: In Section II the simultaneous equation model is developed. The results of the estimated model are presented in Section III. Conclusions and suggestions for further research are briefly discussed in the final section.

${ }^{3}$ Edwards (1989) provides an excellent review of these studies.

${ }^{4} \mathrm{~A}$ study examining the issue of simultaneity, in detail, is in progress. 


\section{MODEL}

As a starting-point, we apply the theoretical framework presented in Afridi (1995) to determine the equilibrium path of RER. The study develops the following relationship:

$$
\begin{aligned}
& R E R=a_{0}+a_{1} T O T+a_{2} C A P+a_{3} C P+ \\
& a_{4} E X D C+a_{5} \text { Tech }+a_{6} G C+U_{1} \quad \ldots \quad \ldots \quad \ldots
\end{aligned}
$$

where:

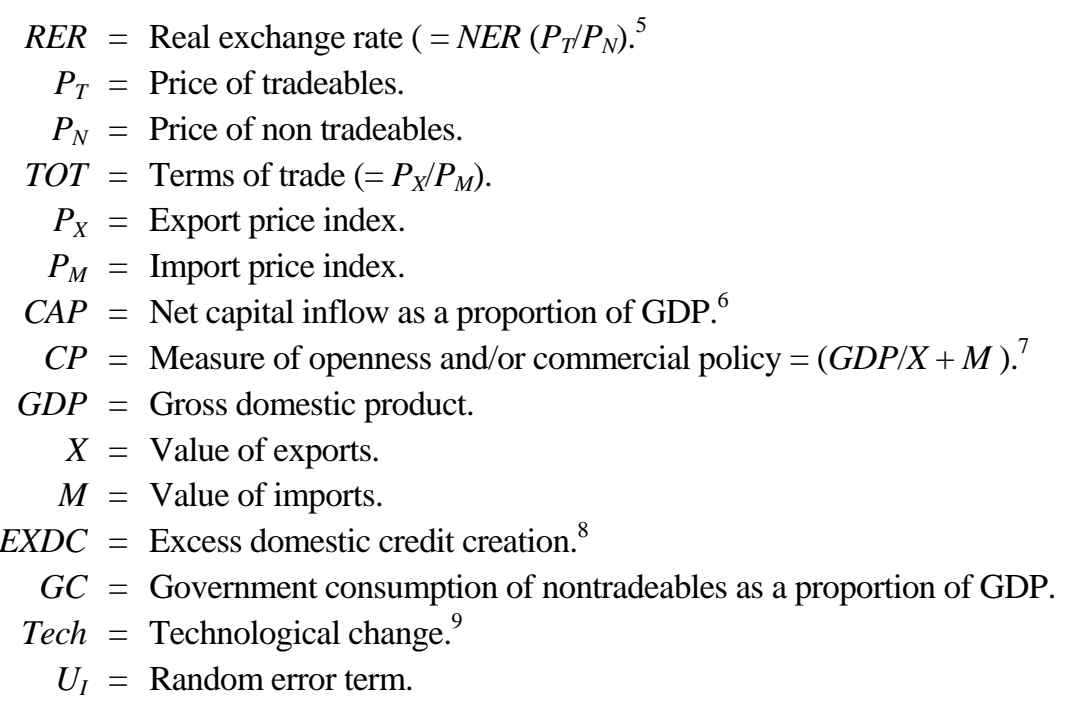

Before the discussion of estimated parameters of Equation 1, we mention, briefly, the expected relationship between the RER and the explanatory variables. ${ }^{10}$ While affecting the RER, changes in the terms of trade (TOT) can result in both 'income effect' and 'substitution effect'. The net result would depend on the relative strength of the income effect and the substitution effect.

\footnotetext{
${ }^{5}$ We use wholesale price index (WPI) of the United States as a proxy for $P_{T}$ and Pakistan's consumer price index (CPI) as a proxy for $P_{N}$

${ }^{6} \mathrm{CAP}$ is defined as percentage share of net foreign resource inflow in gross domestic product (GDP). Net foreign resource inflow is defined as the sum of net foreign borrowing (NFB), foreign aid (AID), and net foreign incomes from abroad (NFIFA).

${ }^{7}$ For the present study we measure 'CP' as ratio of GDP to tradeables. Alternative measures of ' $\mathrm{CP}$ ' can be tariff revenues as a ratio of GDP, average statutory tariff rate and rate of export subsidy.

${ }^{8}$ Assuming a constant velocity of the money supply EXDC is defined as creation of domestic credit in excess of devaluation, foreign inflation and technological growth.

${ }^{9}$ We use the growth rate of GDP per capita as a proxy for technological change (Tech.).

${ }^{10}$ For details, see Afridi (1995).
} 
The changes in capital market affect capital inflows and as a result are expected to change the equilibrium RER. The ultimate impact on the RER would depend on whether the net capital inflow is utilised for imports or for domestic production. If capital inflow is utilised in the importables then RER will not be affected. However, if capital inflow is used for the production of nontradeables then the conversion of foreign exchange in domestic currency will increase the money supply and as a result the prices of non-tradeables will go up causing an appreciation of the real exchange rate.

Presence of commercial policy-distortions may increase the ' $\mathrm{CP}$ ' and thus reduce the openness of the economy. If countries follow import substitution policies, prices of importables would be higher resulting in higher wages and higher prices of nontradeables also. Given constant foreign price of tradeables and a fixed exchange rate, the RER would appreciate.

Excess domestic credit creation ('EXDC'), given the price of tradeables, leads to a rise in the price of non-tradeables, thus causing a real exchange rate appreciation.

The impact of technological change (Tech) on RER is called the "Balassa effect". Balassa (1964) has shown that if productivity improvements are higher in the traded goods sector then, in the long run, the resulting fall in the price of tradeables relative to the price of nontradeables, should lead to RER appreciation.

Similarly, rise in government consumption on non-tradeables (GC) increases the demand and price of non-tradables generating income and substitution effect. ${ }^{11}$ Thus, increase in GC may lead to currency appreciation if income effect dominants and the RER may depreciate if substitution effect dominates.

The following the argument put forward by Schafer (1989) we also endogenise 'CAP' and 'CP'. Schafer argues that, "If the real exchange rate has been overvalued during the current period, then the capital account balance for the current period is affected by the real exchange rate. Hence, net capital inflows are likely to be endogenous". Similarly RER affects the components of measure of CP, i.e., GDP, exports and imports. Thus, we expect that CP is also affected by changes in RER. The following two equations are specified, while endogenising 'CAP' and ' $\mathrm{CP}$ ', respectively:

$$
\begin{aligned}
& C A P=b_{0}+b_{1}(E X D C)+b_{2}(C P)+b_{3}(T e c h) \\
& +b_{4}(R E R)+b_{5}(K t)+U_{2} \quad \ldots \quad \ldots \quad \ldots \quad \ldots \\
& C P=c_{0}+c_{1}(G C)+c_{2}(T O T)+c_{3}(E X D C) \\
& +c_{4}(C A P)+c_{5}(R E R)+c_{6}(G D P 1)+U_{3} \quad \ldots \quad \ldots
\end{aligned}
$$

where:

$K t=$ Capital stock.

${ }^{11}$ The financing of government consumption of non-tradeables may crowd out private demand for non-tradeables. 
$G D P 1=$ Lagged gross domestic product.

$U_{2} \& U_{3}=$ Random errors in Equations (2) and (3), respectively.

A brief description of all the explanatory variables in Equations (2) and (3) is as follows. 'EXDC' affects the net capital inflow. If 'EXDC' substitutes for 'CAP' then the impact would be negative. However, the effect would be positive if the two variables are complementary. 'CP' as a measure of openness directly affects 'CAP', i.e., a rise in the openness of the economy encourages the net capital inflow. Similarly, the long-run productivity growth (Tech) is expected to encourage net foreign capital inflow. The ' $K_{t}$ ' variable is included in Equation (2) to capture the impact of gap between desired and actual capital stock. This is because a big gap in two capital stocks may result in high rates of return on investment, which in turn, may attract foreign capital.

In Equation (3), if increase in government consumption crowds-out exports then it is likely to have an adverse effect for the openness of the economy. The impact of terms of trade (TOT) works through the 'price effect' on both exports and imports. Favourable 'TOT' induce a rise in exports and hence openness will be high. If the impact of ' $E X D C$ ' on tradeables is greater than the impact on nontradeables then openness will improve. Similarly, a rise in rate of capital inflow is likely to improve openness if it is utilised more in the traded goods sector then in nontradables. Finally, if the lagged GDP provides a growth momentum then the current level of the GDP and the current level of trade surplus is expected to rise.

It may be pointed out that the three equations model presented above may not account for all the interactions of a fully specified RER-model, nevertheless, it can be rigorously used to identify the presence of simultaneity bias and its possible influence on the estimates of the RER-model.

\section{RESULTS}

We begin our analysis by estimating the three equations separately by applying the method of Ordinary Least Squares (OLS). Estimated equations are reported in first three columns of Table $1 .^{12}$ Next, the model is estimated simultaneously by applying 2SLS technique, and the results are reported in Columns 4-6 of Table 1. We discuss the results of the simultaneous equations model in detail.

Interestingly, adjustment for simultaneity bias reduces the size of the coefficient of ' $\mathrm{CP}$ ' but the size of the coefficient of 'CAP' increases significantly. This result indicates that the impact of 'CAP' on RER declines sharply whereas the impact of 'CP' increases as we adjust for the simultaneity bias.

The results suggest that a 1 percent increase in 'GC' leads to approximately 0.7 percent depreciation of RER. The coefficient of TOT is positive but statistically

${ }^{12}$ For this study all the data has been obtained from $\operatorname{IMF}(1987,1995)$ and Government of Pakistan (1996). For details of the 2SLS-technique, see Dhrymes (1974). 
Table 1

Results: Single-equation and Simultaneous-equations Estimation

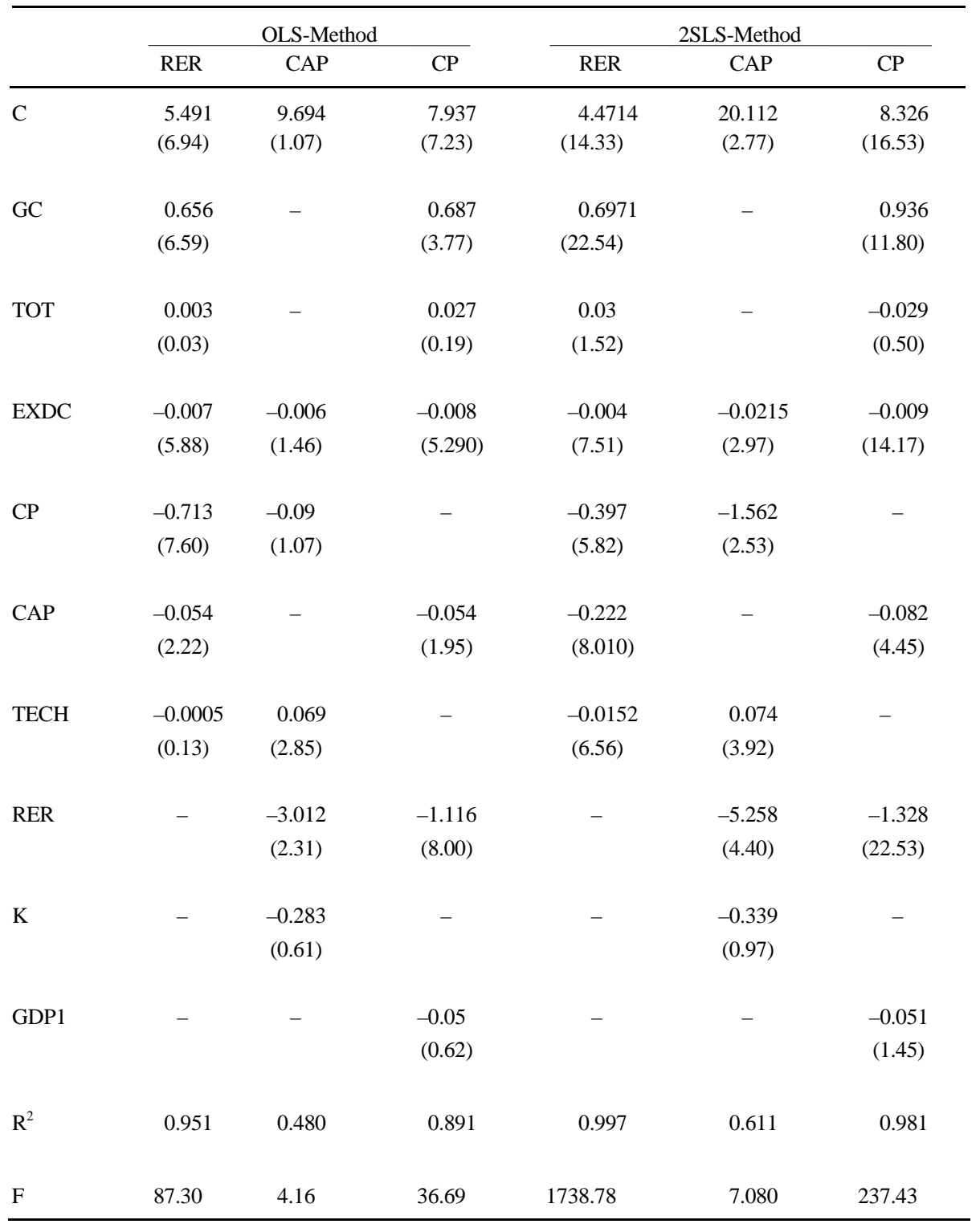

Note: All the variables are expressed in natural log-form.

* $t$-statistics are reported in parentheses.

OLS: Ordinary Least Squares.

2SLS: Two-stage Least Squares. 
insignificant which lend support to the finding of Afridi (1995) that income effect of changes in TOT on the RER dominates the substitution effect. Our results show that excess domestic credit creation significantly contributes to RER-appreciation. Similarly, the 'openness' contributes to appreciation of the RER.

The most significant impact of endogenising 'CP' and 'CAP' is on the coefficient of 'Tech'. The OLS estimation of the relationships shows that the impact of technological progress is negative though statistically insignificant. The relationship becomes statistically significant when we apply 2SLS-technique. Thus implying that the technological progress in the traded goods sector is faster than in the nontraded goods sector, resulting in the appreciation of RER.

The impact of excess domestic credit creation on 'CAP' turned out to be negative. This result indicates that excess supply of domestic credit substitutes for the foreign capital inflow. Similarly, as expected, reduction in openness significantly reduces the inflow of foreign capital. The results further show that an appreciation of RER reduces the inflow of foreign capital. The impact of domestic capital stock on CAP is negative but statistically insignificant.

Equation (3) further shows that increase in the government expenditure has a positive effect on CP. The impact of TOT is negative but statistically insignificant. The result shows that an increase in the price of exports relative to the price of imports encourages openness. An important finding of this equation is that the excess domestic credit creation has a negative and statistically significant impact on CP. This shows that credit creation is also used for the expansion of the tradeable sector. Similarly, the coefficient of 'CAP' shows that a higher rate of capital inflow helps the country to open its economy. As expected, the results indicate that RER-depreciation facilitates openness of the economy. The lagged output has desired but insignificant effect on ' $\mathrm{CP}$ ', which indicates that the lagged output does provide a growth momentum for the economy and as such helps in opening the economy, but the impact is not statistically significant.

\section{CONCLUSIONS}

The objective of the study is to examine whether the estimates of RER-model suffer from simultaneity bias. For this purpose, we have developed a Simultaneous Equations Model. The results suggest that 2SLS-technique gives meaningful coefficient estimates which can be utilised to draw more reliable policy recommendations.

Based on these findings we can say that:

(i) Both the monetary and real variables affect the equilibrium path of RER significantly. Therefore, controlling only the monetary side of the economy may not be sufficient to maintain a competitive and stable RER.

(ii) Controlling domestic prices instead of repeated devaluations of currency may be 
another way to maintain a stable RER.

(iii) The changes in the nontraded goods sector also affect RER significantly. Therefore, policies geared for efficient and optimal use of resources in this sector can also play an important role in maintaining a competitive and stable RER.

Based on the results of this study, we intend to develop a complete model determining the equilibrium path of the RER. Such an exercise will help us to determine the 'real' effectiveness of exchange rate as a policy tool to solve a number of problems, particularly the problems in export expansion and in improving current account deficit.

\section{REFERENCES}

Afridi, U. (1995) Determining Real Exchange Rates. The Pakistan Development Review 34:3 263-276.

Balassa, B. (1964) The Purchasing Power Parity Doctrine: A Reappraisal, Journal of Political Economy 72: 584-596.

Chishti, S., and M. A. Hasan (1993) What Determines the Behaviour of Real Exchange

Rate in Pakistan? The Pakistan Development Review 32:4 1015-1028.

Dhrymes, P. J. (1974) Econometrics: Statistical Foundations and Application. New York: Springer Verlag.

Edward, S. (1989) Real Exchange Rates, Devaluation and Adjustment: Exchange Rate Policy in Developing Countries. Mass: The MIT Press.

International Monetary Fund $(1987,1995)$ International Financial Statistics-Yearbook. Washington, D. C: IMF.

Pakistan, Government of (1996) Pakistan Economic Survey 1995-96. Islamabad: Finance Division, Economic Advisor's Wing.

Schafer, H. (1989) Real Exchange Rates and Economic Performance: The Case of SubSaharan Africa. Unpublished Ph.D. Dissertation, Department of Economics and Business, North Carolina State University, Raleigh, North Carolina, USA. 


\section{Comments}

This paper is well written. It adds much to our understanding of what determines the behaviour of real exchange rate, an issue which has been at the centre of economic policy discussions since the inception of managed floating exchange rates in Pakistan. The paper aims to develop a simultaneous equation model identifying some real and monetary variables determining the equilibrium path of Pak-rupee real exchange rate over the period 1960-94. Applying both single- and simultaneous-equation econometric procedures, the authors produce results indicating that almost all variables including government consumption of tradeables, GDP, excess domestic credit, net capital inflow GDP (defined as the sum of net foreign borrowing, foreign aid, and net foreign income from abroad), the sum of GDP exports and imports and technological progress (proxied by the GDP growth) significantly affect the behaviour of Pak-rupee real exchange rate. However, terms of trade appear to have no impact on it. Based on these results, the authors suggest controlling both monetary and real variables, together with domestic prices, instead of repeated devaluations, to maintain stability in Pak-rupee real exchange rate.

I would have absolutely no problems with these results if the conventional OLS procedures employed by the authors were statistically appropriate. However, I have my reservations about these procedures, the inference derived from the results obtained from them, and the data involving structural breaks resulting from nominal exchange rate regime shifts. Conventional OLS procedures may produce a spurious relationship due to non-stationarity of the variables underlying the real exchange rate model tested by the authors. The non-stationarity property of these variables has also serious implications for the conventional test statistics, such as $t, F$ and $D W$, which have no longer limiting standard distributions and, therefore, become inappropriate for making an inference about the OLS estimates. It is, therefore, suggested that cointegration be used to obtain superconsistent estimates of the OLS parameters (despite the presence of serial correlation, heteroscedasticity, and simultaneity) and the West (1988), and corrected $t$-statistic be used to make a reliable inference from the OLS estimates. But it must be borne in mind that structural breaks in time-series may cause difficulties concerning integration and cointegration by making stationary time series to show unit roots. This problem could, however, be got over by employing cointegration tests proposed recently by Campos et al. (1996) and Gregory and Hansen (1996).

I have also some observations about defining and modelling the real exchange rate. My first observation is that the authors use a very restrictive definition of the real exchange rate (by considering it to be equal to the nominal exchange rate deflated by the ratio of the domestic non-traded goods prices to the foreign traded 
goods prices), which requires the (domestic) country to be dependent and producer of non-traded goods only. Moreover, this definition seems to have little economic theory behind it. Therefore, I would like to suggest the PPP definition be used where the real exchange rate is defined as the nominal exchange rate deflated by the domestic price index to the foreign price index. One benefit of using the PPP definition is that it provides a basic economic model explaining the behaviour of the real exchange rate. The PPP model shows that while the nominal exchange rate is determined by nominal magnitudes (i.e., by differences between domestic and foreign prices), the real exchange rate is determined by real magnitudes (i.e., by the internal price structure across countries). The PPP model thus shows that the real exchange rate is determined by the internal price structure, which in turn is determined by the ratio of traded to non-traded goods prices across countries. Another benefit is that this model could be easily extended to incorporate the impact on the real exchange rate of other real and monetary variables such as terms of trade and interest rates, providing more well-established links underlying goods and asset markets across countries to look into more appropriate real and monetary variables affecting the path of the real exchange rate.

The authors should also mention the study by Chishti and Hasan (1993).

\section{REFERENCES}

Campos et al. (1996) Cointegration Tests in the Presence of Structural Breaks. Journal of Econometrics 70: 187-220.

Gregory, and Hansen (1996) Residual-based Tests for Cointegration in Models with Regime Shifts. Journal of Econometrics 70: 99-126.

West (1988) Asymptotic Normality When Regressors Have a Unit Root. Econometrica 56: 1397-1418.

University of Azad Jammu and Kashmir,

Razzaque H. Bhatti Muzaffarabad. 